Digitalizacja archiwalnych numerów czasopisma naukowego Analecta Cracoviensia 1-24 (1969-1992) i ich publikacja w otwartym dostępie - zadanie finansowane w ramach umowy 672/P-DUN/2017 ze środków Ministra Nauki i Szkolnictwa Wyższego przeznaczonych na działalność upowszechniającą naukę

\title{
ŜW. KAZIMIERZ W POLSCE I NA LITWIE W OKRESIE NIEWOLI NARODOWEJ
}

Okres niewoli narodowej nie jest chronologicznie równy dla Polski i Litwy. Nie chcąc wchodzić w szczegóły konieczne do uściślenia dat początkowych i końcowych tego okresu, ograniczyłem temat wykładu zasadniczo do XIX wieku, zachowując przy tym jego tytuł sformułowany przez organizatorów krakowskiego sympozjum o św. Kazimierzu. Napotkałem wszakże na przerażający brak literatury przedmiotowej, o czym najwyraźniej świadczy biogram św. Kazimierza w Hagiografii polskiej ${ }^{1}$. Podane w nim informacje o jego kulcie gwałtownie urywają się na wieku XVII. Autor biogramu ks. Rybus nie miał po prostu materiałów, by przedstawić rozwój czci tego Swiętego w następnych stuleciach.

Jak przedstawia się stan literatury przedmiotowej obecnie? Odpowiedź na to pytanie stanowi pierwszą i nawet dość obszerną część wykładu. Bibliografia do wspomnianego biogramu, starannie zebrana przez o. R. Gustawa OFM, wymienia kilkanaście pozycji, druków samoistnych i artykułów opublikowanych w XIX i XX wieku. Z XIX stulecia tylko jedna sugeruje swoim tytułem, że zajęła się dziejami czci św. Kazimierza. Jest to broszura autorstwa ks. A. Lipnickiego pt. Zycie, cuda i cześć świętego Kazimierza, królewicza polskiego, wielkiego księcia litewskiego (Wilno 1858, ss. 324). Nawet jej drugie wydanie z r. 1907, choć powiększone i poprawione, tylko w minimalnym stopniu zawierało wiadomości o kulcie Swiętego w XIX wieku.

W naszym stuleciu, przed drugą wojną światową opublikowano dwa artykuły, co do których mogłoby się wydawać, że wzbogacą zasób wiedzy $\mathrm{w}$ interesującym nas temacie. Pierwszy $\mathrm{z}$ nich ks. S. Niewęgłowskiego ${ }^{2}$ zajmuje się koniecznością szerzenia czci, a nie jej dziejami. Drugi artykuł, anonimowy, pt. Kult św. Kazimierza w Polsce („Słońce” 8, 1935, s. 36 n.) okazał się nieosiągalny w okresie przygotowywania wykładu.

U ks. Niewęglowskiego znajduje się wszakże jedno zdanie, które trzeba

1 Hagiografia polska. Stownik bio-bibliograficzny, pod red. o. Romualda G usta wa OFM, t. 1, Poznań 1971, s. 738-757.

$2 \mathrm{~S}$. Ni ew ęł łow ski, W sprawie kultu św. Kazimierza, „Miesięcznik Katechetyczno-Wychowawczy" 23 (1934) s. $102-117$. 
zacytować: ,[...] kult św. Kazimierza, niegdyś tak wielki w narodzie naszym, że aż doszedł do Neapolu, Palermo, nie mówiąc o Niemczech, Belgii i Rzymie, dziś nawet wśród nas zmalał" ". Smutne to stwierdzenie wyjaśnia również brak publikacji o dziejach tego kultu. Jedno i drugie - osłabienie czci i brak opracowań - dziwi, gdy weźmie się pod uwagę, że w pierwszej połowie naszego stulecia obchodzono dwukrotnie jubileusz świętokazimierzowy: w r. 1921 - 400-lecie kanonizacji, w 1934 - 450-lecie śmierci ${ }^{4}$. Dodać trzeba, że nie obrodziły publikacje na interesujący nas temat również $w$ latach po II wojnie światowej, chociaż i my w r. 1958 świętowaliśmy jubileusz św. Kazimierza: 500-lecie jego urodzin ${ }^{5}$.

Luka została częściowo wypełniona dopiero w r. 1970, gdy ks. Florian Niewiero wydrukował dość obszerną rozprawę: Dzieje kultu św. Kazimierza $w$ kraju $i$ za granica ${ }^{6}$. Wyszedłszy $\mathrm{z}$ uzasadnionego założenia, że „o dziejowym rozwoju jego kultu zarówno w kraju, jak zwłaszcza za granicą, opracowań naukowych prawie nie mamy", postawił sobie przeto ambitny cel, iż ,zadaniem niniejszej pracy będzie, na podstawie jej autorowi dostępnych źródeł, możliwie wyczerpująco przedstawić na przestrzeni prawie pięciu wieków - rozwój czci św. Kazimierza w Polsce, jak również w innych chrześcijańskich krajach poza Polską" 7 . Wbrew tej zapowiedzi dostarczył ks. Niewiero tak skąpo informacji o kuilcie św. Kazimierza w XIX wieku, że nie starcza ich na jeden wykład. Oczywiście nie jest to jego wina, ale raczej dostępnych mu, a skąpych źródeł. Czy mogą jednak istnieć jeszcze jakieś inne?

W poszukiwaniu odpowiedzi na to pytanie zbadano opublikowane już trzy tomy Stownika Polskich Teologów Katolickich (Warszawa 19811982). Nie ulega bowiem wątpliwości, że do tego Słownika przeprowadzono kwerendę $w$ większej liczbie czasopism, niż mógł to uczynić ks. Niewiero, czy nawet o. Romuald Gustaw. Badanie jednak wykazało, że w Słowniku nie ma żywotów św. Kazimierza ani artykułów o nim, które nie byłyby wcześniej znane. $Z$ tego badania udało się wszakże wyprowadzić wniosek, że polska hagiografia w XIX wieku tkwiła w pewnym zastoju. Trzy tomy Słownika uwzględniają w XIX wieku dorobek 456 pisarzy. Spod ich pióra wyszło 40 żywotów polskich świętych i błogosławionych oraz 91 żywotów świętych i błogosławionych Kościoła powszechnego. Nie jest to wielka liczba, a trzeba dodać, że poszczególne

3 Tamże, s. 104.

${ }_{4}^{4}$ M. Bart y now ski, Obchód $w$ Wilnie 400 rocznicy kanonizacji św. Kazimierza, „Gazeta Kościelna” 29 (1922) s. 362-363.

$5 \mathrm{Z}$ tej okazji ukazal się artykuł P. Rabikauskas a SJ: Osservazioni sulla storia del culto di san Casimiro, "Asidi” 1958 (Brokolyn N. Y.) s. 305-311, niestety dla mnie nie dostępny.

6 ,Nasza Przeszłość” 33 (1970) s. 61-124.

7 Tamże, s. 61. 
żywoty są objętościowo małe i posiadają charakter publikacji popularnych. Kto się zajmuje czasopismami XIX wieku, dobrze wie, że pur blikowano w nich najczęściej bezimiennie, anonimowo. Teoretycznie więc istnieje możliwość, że nie wszystkie artykuły o św. Kazimierzu zostały uwzględnione w Stowniku. Aby upewnić się co do tego, szczegółowo przeglądnąłem kilka czasopism kościelnych z XIX w.

Z pierwszej połowy tego stulecia poddano badaniu „Gazetę Kościelną”, wydawaną w Poznaniu przez ks. J. Jabczyńskiego w latach 1843-1849. Znaleziono w niej zaledwie parę artykułów hagiograficznych, ale żadnego o św. Kazimierzu, nawet żadnej wzmianki o nim.

Z połowy XIX wieku uwzględniono „Przegląd Poznański”, redagowany przez ks. Jana Koźmiana w latach 1845-1865. Czasopismo liczy 38 tomów, o przeciętnej objętości każdego około 500 stronic. W ich bogatej tematyce tylko dwa artykuły odnoszą się do św. Kazimierza: pierwszy o Godzinkach NMPanny i hymnie św. Kazimierza ${ }^{8}$ z rękopisu monachijskiego, drugi o św. Kazimierzu, obrońcy Korony i Litwy ${ }^{9}$.

O innych świętych także niewiele znajdujemy artykułów w „Przeglądzie Poznańskim". Podano jedynie krótki życiorys królowej Jadwigi i bł. Jolanty, wydrukowano wyjątek z dramatu: Szczepanowski czyli męczeństwo św. Stanisława ${ }^{10}$, a $\mathrm{w}$ dziale Omówienia książek poinformowano o dwóch żywotach św. Stanisława Kostki oraz o żywocie bł. Andrzeja Boboli i bł. Czesława Odrowąża ${ }^{11}$.

W ostatnim ćwierćwieczu XIX stulecia wychodził w Poznaniu „Przegląd Kościelny" ks. A. Jaskulskiego (1879-1896). Na przestrzeni tych osiemnastu lat, w 36 tomach (każdy o objętości około 400 stronic) tylko dwukrotnie uczyniono wzmiankę o św. Kazimierzu. Jeden raz w artykule: Swięci $w$ ksiązęcych rodzinach $w$ wiekach średnich ${ }^{12}$, drugi raz $\mathrm{w}$ dziale bieżących informacji z życia kościelnego na ziemiach polskich, krótko donosząc, że w Krakowie odbędą się u o. reformatów uroczystości z okazji 400-lecia śmierci św. Kazimierza ${ }^{13}$. Już na pierwszy rzut oka widać jednak, że brakuje kolejnej informacji o przebiegu owej uroczystości, jak również nie umieszczono żadnego artykułu okolicznościowego z racji tego jubileuszu. Jest to tym dziwniejsze, że właśnie w Poznaniu pamiętano o nim, jak świadczy broszurka wydana tamże w r. 1884 przez W. Simona: Swięty Kazimierz, królewicz polski, Patron Królestwa Polskiego. Na pamiątkę czterechsetnej rocznicy śmierci (ss. 35).

\footnotetext{
8 „Przegląd Poznański” 28 (1859) s. 103 n.

9 Tamże, 27 (1859) s. $31-44$.

10 Tami̇e, 17 (1853) s. $452 \mathrm{n}$.

11 Tamże, 18 (1854) s. $537 ; 34$ (1862) s. 278.

12 „Przegląd Kościelny" 8 (Poznań 1886) s. 202.

13 Tamże, 5 (1884) s. 282.
} 
Wydawać by się mogło, że poznańskie czasopisma, oddalone tak bardzo od Wilna, centrum kultu św. Kazimierza, są mało reprezentatywne dla omawianego zagadnienia. Kto jednak szczegółowiej zna historię zaborów, wie, że w jednym zaborze pisano wiele właśnie o sprawach kościelnych i politycznych drugiego zaboru, bo było to bezpieczniejsze ze względu na cenzurę. Wielkopolska interesowała się w szczególniejszy sposób Kościołem w zaborze rosyjskim.

Dla porównania jednak przeglądnięto również warszawski „Przegląd Kościelny" od pierwszego numeru w r. 1863 do końca XIX wieku. Nie ma w nim artykułu o św. Kazimierzu i w ogóle mało jest artykułów hagiograficznych. Czasopismo to prowadziło szeroki dział Korespondencji, w którym nie brakowało doniesień $\mathrm{z}$ archidiecezji mohylewskiej, bądź z Petersburga. Rzadko jawiła się korespondencja z Wilna. Wyjątkowo więcej było jej w latach 1883-1884. Tym bardziej jest rzeczą znamienną, że nie podano żadnej wzmianki o jakiejkolwiek uroczystości z okazji 400-lecia śmierci św. Kazimierza, chociaż informowano o nabożeństwie w katedrze wileńskiej właśnie 3 i 4 marca $1884 \mathrm{r} .{ }^{14}$

\section{II}

Każdy rozwinięty kult świętego posiada pewne formy instytucjonalne: sanktuaria, wezwania kościołów i ołtarzy, bractwa, odpusty itp. Jak działały one w XIX wieku w odniesieniu do czci św. Kazimierza?

W Wilnie istniały, jako spuścizna ubiegłych stuleci, dwa ośrodki kultu. $\mathrm{Z}$ nich pierwsze miejsce należy się kaplicy św. Kazimierza (zwanej tė̇ Kaplicą Królewską). Budowę kaplicy ukończono w r. 1636, wtedy też 14 sierpnia - złożono w niej relikwie św. Kazimierza. Kaplica miała kształt kwadratu, zewnątrz była z piaskowca szwedzkiego, wewnątrz z marmuru. W ołtarzu znajdował się obraz św. Kazimierza (postać w srebrnej szacie z trzema rękami, w dwóch prawych trzymał lilię, a w lewej różaniec). Nad obrazem mieściła się trumna $\mathrm{z}$ relikwiami ${ }^{15}$. Według relacji ks. A. Lipnickiego (1858), w kaplicy znajdowało się wiele dawnych pamiątek, przypominających dzieje życia św. Kazimierza, wielowiekową cześć narodu dla tego ojczystego Patrona oraz świetną przeszłość kraju ${ }^{16}$. W XIX wieku odnowiono kaplice gruntownie co najmniej dwa razy: w $r$. 1838 i 1878. Pierwsza renowacja był potrzebna, bo kaplica od schyłku XVIII wieku znajdowała się $\mathrm{w}$ zaniedbaniu, co z kolei - jak stwierdza

14 „Przegląd Kościelny” 12 (Warszawa 1884) s. 237.

15 X.Y.Z., Kartka $z$ dziejów Kościola katolickiego $w$ Polsce rosyjskiej. T. II: Biskupstwo wileńskie, Kraków 1889, s. 90.

18 A. Li pnicki, jw., s. 181. 
ks. A. Lipnicki - osłabiło pobożność ludu i świetność nabożeństw. Bezpośrednią przyczyną zaniedbania było to, że po śmierci ks. Macieja Tyszkiewicza, jej ostatniego prepozyta, dochód prepozytury kaplicy przejęła w r. 1808 Komisja Edukacji Narodowej na fundusz Uniwersytetu, a potem Akademii Duchownej w Wilnie. Przejściowo w r. 1813 udało się zawrzeć układ z KEN, na mocy którego część dochodów przeznaczono na utrzymanie prepozyta i wiceprepozyta, a także dwóch psałterzystów i sześciu chóralistów do codziennego odmawiana, a raczej śpiewania Officium parvum de Beata Maria Virgine oraz na odprawianie 365 mszy św., tzw. funduszowych. Później włączono ten cały dochód do ogólnego funduszu duchowieństwa rzymsko-katolickiego w Rosji ${ }^{17}$. Druga renowacja w r. 1878 została przeprowadzona z dużym nakładem sił i pieniędzy. Jej kształt wynosił prawie asiem tysięcy rubli srebrnych, z czego ponad dwa tysiące siedemset wzięto $\mathrm{z}$ sum po zmarłych księżach ${ }^{18}$.

Znane trudności materialne Kościoła katolickiego w zaborze rosyjskim, wywołane najpierw wojnami napoleońskimi, a potem ostracyzmem carskich zarządzeń, stanowiły $\mathrm{z}$ pewnością przyczynę braku liczniejszych dobroczyńców z darami na uświetnienie kaplicy św. Kazimierza, takich jak w r. 1839 bp Andrzej Benedykt Kłągiewicz ${ }^{19}$, a w r. 1893 ks. prałat Felicjan Biedrzyński. Ten ostatni ofiarował 3 tysiące rubli na ułożenie marmurowej posadzki w kaplicy ${ }^{20}$.

Podczas każdej renowacji kaplicy dwukrotnie otwierano trumnę z relikwiami. W r. 1838 (12 i 24 listopada) dokonano otwarcia trumny i oglądu relikwii, które znaleziono $\mathrm{w}$ ilości podanej $\mathrm{w}$ dokumentach. Na zarządzenie bpa A. B. Kłągiewicza i w jego obecności zabrano część relikwii „,in usum Ecclesiarum ad earum ornamentum et patrocinum Divi Tutelaris conciliandum" "21. Te cząstki relikwii najczęściej wkładano do portatyli. Przekazywane wraz z nimi do kościołów służyły, choć w wąskim zakresie, szerzeniu czci św. Kazimierza. W r. 1860 głośne było w Wilnie przekazanie partykuły relikwii kościołowi parafialnemu w Trenczynie i katedrze w Nitrze na Węgrzech ${ }^{22}$.

Drugim ośrodkiem kultu św. Kazimierza w Wilnie, ale tylko do r. 1832, był kościół pod jego wezwaniem, ongiś jezuicki. Ufundowany w r. 1604 przez Władysława IV, kanclerza wielkiego litewskiego Lwa Sapiehę i biskupa wileńskiego Benedykta Woynę, był złączony z klasztorem i kolegium jezuickim. Uznawany za arcydzieło architektury XVII wieku, został zeszpecony przeróbkami po kasacie Towarzystwa Jezuso-

17 Tamże, s. $169-170$.

18 F. Niewiero, jw., s. 95.

10 Tamże, s. 107.

20 Tamże, s. 97.

21-22 Tamże, s. 104; ks. Niewiero prizetłumaczył to zdanie: „by za wstawiennictwem św. Patrona przebłagać Baga oraz użyć potrzebnych relikwii do konsekracji portatyli". 
wego. Wtedy przeszedł on w posiadanie kanoników regularnych od pokuty, a od r. 1799 pełnił funkcję kościoła parafialnego. Kanonicy regularni utracili go w r. 1812 i wówczas prawdopodobnie, podczas moskiewskiej wyprawy Napoleona, uległ zniszczeniu i znieważeniu, gdyż bp Hieronim Strojnowski wydał 24 lutego 1815 r. list pasterski, zapowiadający swój przyjazd do Wilna w celu rekoncyliacji tego kościoła, dotychczas spustoszonego i opuszczonego ${ }^{23}$. Po rekoncyliacji i odnowieniu pracowali przy nim księża misjonarze, ale już niedługo. W r. 1832, w ramach represji za powstanie listopadowe, skasował go rząd carski, a w r. 1840 zamienił na katedrę prawosławną ${ }^{24}$. Dla duszpasterskiego działania tego kościoła przed kasatą nie było bez znaczenia, że złączone $\mathrm{z}$ nim kolegium jezuickie oddano w r. 1773 na dom księży emerytów, a w r. 1798 zamieniono na koszary wojsk rosyjskich ${ }^{25}$.

Wykaz innych kościołów pod wezwaniem św. Kazimierza, zarówno na Litwie, jak i w Polsce, podaje ks. Niewiero ${ }^{26}$. Warto wszakże uczynić dwie uwagi do tego wykazu. Pierwsza, że autor korzystał do jego sporządzenia $\mathrm{z}$ informacji udzielonych mu przez kurie biskupie w Polsce oraz z katalogu tytułów kościołów w Polsce, użyczonego mu przez ks. W. Patykiewicza $z$ Częstochowy ${ }^{27}$, i jest to wykaz kompletny. Druga jednak uwaga, że w tym wykazie posługuje się autor niezbyt precyzyjnie raz terminem kościół „fundowany”, kiedy indziej „zbudowany”. Można by więc wnioskować, że niektóre z nich powstały w XIX wieku i otrzymały wówczas tytuł św. Kazimierza. W rzeczywistości kościoły określone jako „zbudowane” w XIX wieku, istniały wcześniej. Dotyczy to kościoła W Lipniszkach, pow. Lida na Litwie, o którym pisze ks. Niewiero, że zbudowano go w r. $1890^{28}$. Tymczasem powstał on jako kościół drewniany w r. 1511 z fundacji króla Zygmunta I i już w XVI wieku był pod wezwaniem św. Kazimierza. Odnowiony w r. 1804 spalił się w 1890 i został zbudowany jako murowany w $1900{ }^{29}$. Podobnie było z kościołem w Radgoszczy (diec. tarnowska). Ks. Niewiero podaje, że jest pod wezwaniem Przeniesienia Relikwii św. Kazimierza i został zbudowany w r. 1860, co może sugerować jego powstanie dopiero w XIX wieku. Tymczasem zbudowano go $\mathrm{z}$ drzewa już w r. 1661 i wtedy też otrzymał owo unikalne wezwanie, a w r. 1860 został na nowo zbudowany $\mathrm{z}$ cegły ${ }^{30}$. Pewną wątpliwość budzi jedynie kościół w Swinicach (diec. włocławska). Ks.

\footnotetext{
23 J. Kurczew ski, jw., s. 148.

24 X.Y.Z., jw., s. 121.

25 J. Kurczewski, jw., s. 170.

26 F. $\mathrm{N}$ i e wi a r o, jw., s. $113-118$.

27 Tamże, s. 113 (p. 211).

28 Tamże, s. 117.

29 J. Kurczew ski, jw., s. 200; X.Y.Z., jw., s. 235.

so Schematyzm diecezji tarnowskiej na rok 1977, s. 436.
} 
Niewiero informuje, że zbudowano go w r. $1858^{31}$. To prawda, że zbudowano go w XIX wieku, dokładnie w r. 1859 jako murowany, gdy poprzedni kościół spalił się jeszcze w r. 1828. Jednkże istniał on już od średniowiecza, niegdyś pod wezwaniem św. Gotarda ${ }^{32}$. Wezwanie więc zmieniono, trzeba by zbadać kiedy. Możliwe, że stało się to w r. 1859, skoro nowy kościół powstał z fundacji dziedzica wsi Kazimierza Karwowskiego, który imię swego patrona mógł uczynić tytułem kościoła. Byłby to dla XIX wieku jedyny wypadek nadania kościołowi tytułu św. Kazimierza.

Wykaz wszystkich kościołów pod wezwaniem św. Kazimierza ma zrozumiałą wagę w ustalaniu parafialnych ośrodków kultu tego Swiętego. Kult ten przejawiał się głównie w odpustach, lecz one należą do tematu: Św. Kazimierz w liturgii. Można wszakże tutaj przedstawić wspomnianą już relację warszawskiego „Przeglądu Kościelnego" o nabożeństwach w katedrze wileńskiej w dniach 3 i 4 marca 1884 r., a więc związanych $\mathrm{z}$ odpustem ku czci św. Kazimierza. Wileński korespondent podawał $\mathrm{w}$ niej, że 3 marca, w rocznicę prekanonizacji biskupa K. Hryniewieckiego, odprawiono uroczystą sumę, a bezpośrednio po niej nieszpory. Po południu zaś odśpiewano solennie kompletę i urządzono uroczystą procesję z racji następnego dnia, w którym przypadała uroczystość św. Kazimierza „patrona tutejszej diecezji", jak to określił korespondent. W dniu 4 marca biskup celebrował sumę, kazanie zaś wygłosił ks. Jan Kurczewski, profesor Seminarium Duchownego. Po sumie udzielal biskup sakramentu bierzmowania, a po poludniu odprawiono uroczyste nieszpory. Przez następne trzy dni odbywało się 40-godzinne nabożeństwo, zakończone uroczystą kompletną, w której udział wziął biskup. Po niej śpiewano suplikacje i psalm Bóg naszq ucieczkq, następnie w kaplicy św. Kazimierza odmówiono litanię i udzielono błogosławieństwa Najświętszym Sakramentem ${ }^{38}$. Korespondent nie wyjaśnił, czy to kilkudniowe nabożeństwo urządzono wyjątkowo z racji jubileuszu 400-lecia śmierci św. Kazimierza (jeszcze raz warto podkreślić, że $w$ cytowanej relacji nie ma ani słowa o tym jubileuszu), czy też co roku tak obchodzono odpust św. Kazimierza.

Do dziejów folkloru należą wiosenne targi w dniu św. Kazimierza, zapoczątkowane w XVIII wieku, a z biegiem czasu rozwinięte w bardzo popularny kiermasz pod nazwą „Kaziuka”. Utrwalał on wszakże w świadomości ludzi imię Patrona i kraju, zwłaszcza że kiermasz przez długi czas urządzano na placu katedralnym, w pobliżu kaplicy św. Kazimie-

31 F. Niewiero, jw., s. 116.

82 Rocznik diecezji włocławskiej. Rok 1972, s. 321.

${ }^{8 s}$ „Przegląd Kościelny” 12 (Warszawa 1884) s. 237. 
rza. Dopiero gdy naprzeciwko tej kaplicy postawiono pomnik carycy Katarzyny II, przeniesiono kiermasz na rozległy plac na Łukiszkach ${ }^{34}$. Tradycja jednak pozostała.

III

Przed wiekiem XIX gorliwymi propagatorami czci św. Kazimierza były niektóre zakony, zwłaszcza jezuici. Im też najwięcej uwagi poświęcił ks. Niewiero stwierdzając, że „o działalności w tej mierze innych zakonów wiemy niewiele, zresztą nikt tym zagadnieniem bliżej nie zajmował się" ${ }^{35}$. Warto więc wskazać na kościół klasztorny OO. Reformatów w Krakowie jako ośrodek czci św. Kazimierza i postawić hipotezę, że był najważniejszym ośrodkiem na ziemiach polskich zaboru austriackiego. Wprawdzie cała diecezja krakowska czciła św. Kazimierza jako swego drugiego patrona, a w katedrze wawelskiej od połowy XVIII wieku do początków naszego stulecia istniał ołtarz św. Kazimierza, to jednak jego cześć najbardziej rozwijała się w kościele OO. Reformatów. Odpowiadało to tradycji tego zakonu, który razem $\mathrm{z}$ bernardynami, szczególnie na Litwie (ich prowincja była pod wezwaniem św. Kazimierza) już w poprzednich stuleciach krzewił kult tego Swiętego ${ }^{36}$. Odpowiadało to także tradycji samego klasztoru krakowskiego, który powstał dzięki życzliwości króla Zygmunta III i od niego otrzymał obraz św. Kazimierza. Z czasem uzyskał ten obraz sławę łaskami słynącego ${ }^{37}$. Wspomniano już, że w roku 1884 u krakowskich reformatów obchodzono uroczystości 400-lecia śmierci św. Kazimierza, o których poznański „Przegląd Kościelny” uznał za wskazane udzielić informacji swoim czytelnikom. Już dawniej jednak, co roku urządzano w tymże kościele okazały odpust 4 marca, jak o tym świadczy Kalendarz krakowski Józefa Czecha, który podając wykaz ważniejszych uroczystości kościelnych w marcu, zawsze wymienia pod dniem 4 marca: „Swiętego Kazimierza u OO. Reformatów” " ${ }^{8}$. Nie wiadomo od kiedy, może właśnie od roku jubileuszowego, w ich kościele odprawiano 40-godzinne nabożeństwo, i to w dniach 2, 3 i 4 marca ${ }^{39}$. Praktykowano je przez długie lata niewątpliwie $\mathrm{i} w$ tym zamiarze, by przygotowało czcicieli św. Kazimierza na przeżywanie uroczystości odpustowych w duchu eucharystycznym.

s F. Niewier o, jw., s. 109.

35-36 Tamże, s. 110 .

37 Tamże, s. 114.

ss Por. Kalendarz krakowski na rok 1856. Wydanie Józefa Cze cha, marzec (b. p.).

${ }_{39}$ Por. toż na rok 1904, marzec. 


\section{IV}

Najszerszy zasięg w krzewieniu czci św. Kazimierza miały publikacje o jego życiu i nabożeństwie do niego. Ile ich i jakie powstały w XIX wieku? Zestawienie sporządzone na podstawie Hagiografii polskiej wskazuje, że w ubiegłym stuleciu wydano drukiem: 4 publikacje źródłowe (ale tylko pośrednio odnoszące się do św. Kazimierza, np. Acta Tomiciana), 1 poemat A. Krzyckiego Ad tumulum divi Casimiri, 25 życiorysów św. Kazimierza, wliczając $w$ to także hasła encyklopedyczne i krótkie biogramy $\mathrm{w}$ zbiorowych żywotach świętych (7 z tych życiorysów można uznać za typowe żywoty św. Kazimierza), 11 artykułów historycznych, dotyczących problemu autorstwa hymnu Omni die, 3 kazania, 4 nabożeństwa, 2 pieśni, 1 litania do św. Kazimierza, 2 legendy.

$\mathrm{Z}$ pewnością to zestawienie nie jest kompletne (np. opuszczono w $\mathrm{Ha}$ giografii polskiej kazanie bpa A. S. Krasińskiego o św. Kazimierzu ${ }^{40}$ ). Można jednak z tego wykazu wyciągnąć pewne wnioski, zwłaszcza z wykazu żywotów. W kolejności chronologicznej są to następujące teksty:

1. A. Lipnicki, Życie, cuda i cześć św. Kazimierza, królewicza polskiego, wielkiego księcia litewskiego, Wilno 1858, ss. 324; wyd. II Wilno 1907.

2. [A. Kisielewski] Junosza Leszek z Jasienicy, Żywot św. Kazimierza Jagiellończyka, królewicza polskiego, Kraków 1868.

3. A. Chmielowski, Zywot św. Kazimierza wyznawcy podług brewiarza rzymskiego, Łowicz 1884, ss. 19; II wyd. powiększone - Warszawa 1898, ss. 46.

4. K. F a lkiewicz, Swięty Kazimierz, patron Polski, Lwów 1892, ss. 36; II wyd. - Lwów 1911.

5. S. P a ll a n, Sw. Kazimierz, królewicz polski i patron Litwy, Tarnów 1893, ss. 16 .

6. F. J ó z e f ow i c z, Sw. Kazimierz, królewicz polski, patron młodzieży, Lwów 1895, ss. 154; II wyd. — Lwów 1910.

7. F. Pa pée, Swięty Kazimierz, „Ateneum” 1 (1896) s. 521-528.

Do pierwszego wniosku dochodzi się, gdy weźmiemy pod uwagę rok wydania tych żywotów. Żaden $\mathrm{z}$ nich nie powstał w I połowie XIX wieku, co świadczy o małym zainteresowaniu postacią św. Kazimierza. Potwierdza je wypowiedź zamieszczona w „Przeglądzie Poznańskim” w r. 1859: „[...] z boleścią przyznać trzeba, że cześć św. Kazimierza, potężnego przyczyńcy Korony i Litwy, jeśli nie poszła całkiem w zapomnienie, to przynajmniej bardzo ostygła. Rodacy świętego dziś ledwo znają imię

40 „Homiletyka” 2(1898) s. 532-539.

2 - Analecta Cracoviensia 
jego, bo sprawy wyrzucono $\mathrm{z}$ historii narodowej, nawet $\mathrm{z}$ dzieł przeznaczonych dla młodzieży szkolnej"' (s. 44).

Drugi wniosek: prawie wszystkie tytuły żywotów podkreślają związek św. Kazimierza z państwem polskim. Odnosi się wrażenie, że publikowanie jego żywotów miało odpowiadać nie tylko religijnemu zapotrzebowaniu katolików, ale także, a może w pierwszym rzędzie, narodowemu zapotrzebowaniu Polaków.

Gdy czyta się pierwszy z żywotów, pióra ks. A. Lipnickiego z Wilna, dostrzega się wiele akcentów narodowych. Wystarczy wskazać na jego długi fragment, zatytułowany Dialog u Bramy Rudnickiej, w którym dwunastu obywateli recytuje społem: „Jego czcimy i serca jemu oddajemy, w nim Patrona Ojczyzny wszyscy wyznajemy". Dialog kończy się słowami osoby symbolizującej Wilno: „Niech Twe imię w naszej wiekuje pamięci, A Duch Twój w Niebie pomni o swoim narodzie" ${ }^{41}$.

Nie mniej wymowne jest i to, że ks. Lipnicki kończy żywot św. Kazimierza opisem jego kaplicy w katedrze, a kończy ten opis niemal apelem do rodaków: „Przetóż więc całą tę dziś nawet jeszcze wspaniałą orędownika naszego kaplicę śmiało nazwać możemy wielkim i świętym dla nas relikwiarzem. W niej bowiem nad ołtarzem wznosi się trumna ze świętymi i drogimi szczątkami naszego Patrona; w niej się znajduje ów stary a cudowny jego obraz; na jej też ścianach i w całym jej obrębie niemało się mieści dawnych pamiątek od pędzla i dłuta, najwymowniej przypominających już to dzieje świętego i anielskiego życia tego Wyznawcy bożego na ziemi, już to świetną przeszłość naszego kraju, a zarazem wielowiekową a gorącą cześć narodu naszego dla tego ojczystego Patrona. Spieszmy więc z mocną wiarą wszyscy do tej świątyni przed cudowny jego grobowiec, gdzie się tak rzewnie i gorąco modlili pradziadowie nasi i gdzie tak obficie łaski Boże na nich się zlewały, a zarówno i my odejdziemy stąd wysłuchani w potrzebach, wzmocnieni na duchu i z błogą pociechą w sercach, wysławiając powszędy imię ojczystego Patrona" ${ }^{42}$.

Te narodowe akcenty z omawianego żywotu wyeksponował wyraźnie anonimowy autor artykułu w „Przeglądzie Poznańskim” (1859 r.) pt. Swięty Kazimierz obrońca Korony i Litwy. Dostrzega się to już w tytule artykułu, a następnie $\mathrm{w}$ jego treści. Opracowany został na podstawie książki ks. Lipnickiego, ale bardzo krótko podaje życiorys św. Kazimierza, natomiast szeroko omawia pomoc tego Świętego w walce z Moskalami w r. 1518, 1519 i 1654. Zakończenie artykułu jest szczególnie wymowne: „Z prawa się należy cześć świętemu, który nas tak kochał i kocha, a wyjednać nam może ratunek. W latach 1518, 1519, 1654 cudownie

${ }_{41}^{4}$ A. Lipnicki, jw., s. 97 n.

42 Tamże, s. 181. 
przybył w pomoc; błagajmy go, aby z nią pośpieszył tam szczególnie, gdzie schizma zamyka kościoły, ludzi kazi, dusze zatraca i nie zostawia środka między apostazją a męczeństwem" "48.

Silne akcenty narodowe $\mathrm{w}$ obu publikacjach łatwo zrozumieć, jeżeli zwróci się uwagę, że napisano je pięć, cztery lata przed powstaniem styczniowym, kiedy duchowieństwo czynnie angażowało się w działalność narodową. W grę wchodziło także przypominanie społeczeństwu świętych patronów Polski. Jednym z dowodów są dwie publikacje: Patronowie śuięci polscy, Warszawa 1862 (w serii: Czytanki dla Szkót i Ochronek, t. 5) oraz: J. S migielska, A. Borkowska z Chomętowskich, Obrazki $z$ życia światobliwych $i$ bogobojnych Polaków i Polek, Warszawa 1863 (II wyd.). W obu publikacjach umieszczono kilkustronicowe życiorysy św. Kazimierza.

Upadek powstania styczniowego i represje caratu za każdy przejaw narodowej działalności wyeliminowały akcenty narodowe $\mathrm{z}$ publikacji o św. Kazimierzu, ale tylko w zaborze rosyjskim. Przykładem jest żywot pióra ks. Chmielowskiego, wydany w Warszawie w r. 1884, którego tytuł: Żywot św. Kazimierza wyznawcy podtug brewiarza rzymskiego, odbiega od innych wspomnianych wyżej żywotów. Nawet w dodatku „podług brewiarza rzymskiego" wyczuwa się ostrożność, wywołaną lękiem przed wszechwładną cenzurą rosyjską.

Inaczej natomiast było $\mathrm{w}$ zaborze austriackim i pruskim. Prawdopodobnie we Lwowie wydano w tym czasie (druk b.m.d., może 1867?) pieśń do św. Kazimierza: Lilio ze krwi Jagiellonów, autorstwa ks. Ignacego Czeżowskiego TJ (1814-1889). Oto zakończenie tej długiej pieśni:

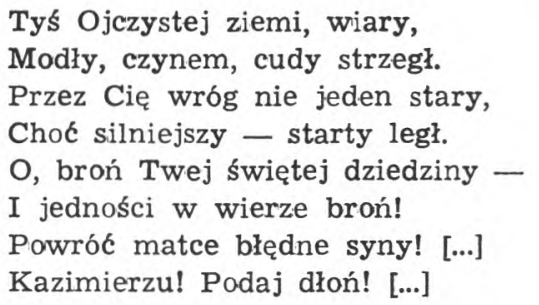

We Lwowie też wydał ks. Walerian $\mathrm{Kal}$ in ka broszurkę $\mathrm{O}$ czci świętych patronów polskich (1883). W Poznaniu zaś ukazała się rok później (1884) wspomniana już broszurka na 400-letni jubileusz: $\$$ w. Kazimierz królewicz polski, patron Królestwa Polskiego. W tytule nie pominięto więc akcentu narodowego.

43 „Przegląd Poznański” 28(1859) s. 44. 
Wiele takich akcentów mamy w drugim co do objętości XIX-wiecznym żywocie św. Kazimierza pióra ks. F. Józefowicza, katechety II gimnazjum we Lwowie. Książeczka ta, wydana w r. 1895, po życiorysie podaje Cuda Kazimierza świętego (s. 28 n.). Krótko relacjonuje trzy cuda: wskrzeszenie umarłego, uzdrowienie chorego i uratowanie topielca, a obszernie opisuje napad Moskali na Litwę w r. 1518 i cudowną wówczas pomoc św. Kazimierza, następnie drugi ich napad w rok później i znów nadprzyrodzoną ingerencję świętego patrona. Wstęp do tych dwóch opisów o napadzie stanowi zdanie: „św. Kazimierz przychodził z cudowną pomocą nie tylko pojedynczym osobom, ale czuwa też nad całym krajem" (s. 33). W omawianym żywocie wydrukowano również pieśń Lilio ze krwi Jagiellonów w pełnym jej brzmieniu.

Nowym akcentem, dobitnie występującym w książeczce ks. Józefowicza, jest wzywanie św. Kazimierza, by strzegł wiary ojców naszych. W okresie martyrologium unitów podlaskich chyba do nich odnoszono wezwania litanii świętokazimierzowej, wydrukowanej w tym żywocie: „Sw. Kazimierzu, wzorze i pociecho nasza, uproś nam zachowanie wiary Ojców naszych! Módl się za nami! Abyśmy wśród utrapień i przeciwności tego życia przy wierze świętej wytrwali! Uproś nam św. Kazimierzu!" (s. 47).

Obok postaci św. Kazimierza, patrona polskiego, już u ks. Lipnickiego jest zarysowana, a u ks. Józefowicza w pełni ukazana postać św. Kazimierza, patrona młodzieży. U ks. Józefowicza było to nie tylko wynikiem jego osobistych zainteresowań jako katechety, duszpasterza młodzieży. W tym okresie szuka się na ziemiach polskich wzorców dla młodzieży męskiej i obok św. Stanisława Kostki, stale aktualnego, stawia się coraz częściej św. Kazimierza. W Tarnowie powstaje bursa św. Kazimierza dla ubogich uczniów, uczęszczających do tamtejszych szkół publicznych ludowych i średnich ${ }^{44}$.

Według relacji ks. Józefowicza, w rozdziale: Kilka rysów z rozpowszechnienia czci św. Kazimierza, w XIX wieku ta cześć rozwijała się szczególnie wśród młodzieży i jej wychowawców, a władze szkolne ją popierały. „I w naszych też czasach - pisze ten autor - powstają liczne ołtarze $\mathrm{z}$ wizerunkiem Swiętego, przed którymi z różnych stron wznosi się co dzień wiele gorących modłów, rzewnych łez i tęsknych westchnień. Szczególnie zaś pocieszającym objawem czci św. Kazimierza jest to, że ucząca się młodzież odczuwa coraz bardziej potrzebę uciekania się pod jego opiekuńcze skrzydła. Z zakładów średnich we Lwowie, gimnazjum niemieckie, gimnazjum Franciszka Józefa i wyższa szkoła realna, na prowincji zaś gimnazjum w Kołomyi, obrały go sobie za szczególniej$73-77$.

44 Zob. I. J. Eobos, Bursa sw. Kazimierza [...], „Currenda” $1887 \mathrm{nr} 9$ s. 
szego Patrona. Postarały się o piękne obrazy Królewicza na płótnie i co roku 4 marca najświetniej obchodzą jego uroczystość, a nawet wyjednano u Stolicy Apostolskiej na ten dzień dla uczniów i profesorów Odpust zupełny. Wreszcie nadmieniam, że władze szkolne, przejęte wielką czcią dla św. Kazimierza, postanowiły obrać go za Patrona szkół ludowych wschodniej Galicji" (s. 42-43).

Oba wzorce, patrona Polski i patrona młodzieży, znakomicie się uzupełniały. Nic więc dziwnego, że ks. A. Jougan dał swemu kazaniu o św. Kazimierzu, wygłoszonym do młodzieży gimnazjalnej w r. 1896, tytuł: O miłości Ojczyzny ${ }^{45}$.

\section{$\mathrm{V}$}

Jaką treść nadawano tym wzorcom w XIX wieku?

Jest to zagadnienie otwarte, wymagające szczegółowszych badań. Chociaż szczupły jest zasób materiałów, które mogłem wykorzystać do tego opracowania, wystarczająco uzasadnione wydają się końcowe wnioski ogólne:

1. W pierwszej połowie XIX wieku nie ma rozwoju czci św. Kazimierza; działają jedynie dawne formy strukturalne jego kultu — sanktuarium wileńskie, odpusty $\mathrm{w}$ parafiach, których kościoły miały wezwanie św. Kazimierza - choć i one doznały osłabienia z powodu wojen napoleońskich i ograniczeń Kościoła przez zaborców, szczególnie rosyjskiego.

2. Widoczne $\mathrm{w}$ połowie XIX wieku większe zainteresowanie czcią św. Kazimierza miało swoje źródło nie tylko w ogólnym rozwoju życia religijnego na ziemiach polskich, ale także narodowej działalności Polaków, którzy włączają w nią rozwój czci świętych Patronów Polski.

3. W ożywianiu czci św. Kazimierza szczególną zasługę należy przypisać żywotowi napisanemu przez ks. Augustyna Lipnickiego, profesora Seminarium Duchownego i prałata kapituły wileńskiej.

4. Ukazany w tym żywocie dość szeroko wzorzec św. Kazimierza „patrona narodu" i zarysowany wzorzec „patrona młodzieży” (bardzo propagowany przez jezuitów w XVII i XVIII w.) stały się pod koniec XIX wieku istotną treścią nauczania o św. Kazimierzu, a także nabożeństw do niego.

5. Urządzony w r. 1884 - choć nie wiemy jeszcze, w jakim zakresie i z jakimi skutkami szczegółowymi - jubileusz 400-lecia śmierci św. Kazimierza, bardzo przybliżył narodowi polskiemu postać tego Świętego.

6. Wykazany na początku brak źródeł i literatury przedmiotowej do dziejów czci św. Kazimierza tym bardziej powinien nakłonić do pod-

45 A. J ouga n, O miłości Ojczyzny, Lwów 1896. 
jęcia badań nad nadawaniem jego imienia na chrzcie; sondażowo uczynione zestawienie imienia Kazimierz z ksiąg metrycznych dwóch poznańskich parafii w XIX wieku dają wyraźny obraz silnego wzrostu ilościowego w r. 1860, co łączy się nie tylko z ogólnym wzrostem liczby urodzeń.

\author{
DER HL. KASIMIR IN POLEN UND LITAUEN \\ IN DER ZEIT DER NATIONALEN ABHÄNGIGKEIT
}

Zusammenfassung

Die Bearbeitung des im Titel angeführten Problems betrifft hauptsächlich des 19. Jh. Die Anzahl der Aufsätze über den Hl. Karsimir ist jedoch gering (vgl. Kap. IV und Anmerkungen: 8, 9, 12, 13). Charakteristisch ist, daß die überwiegende Zahl dieser Veröffentlichungen entweder in Posen oder in Lemberg erschienen ist, obwohl die zwei Städte von dem Zentrum des Kultus von Hl. Kasimir, im Dom zu Wilna, so sehr entfernt waren. In der politischen Situation des von drei Nachbarmächten annektierten Polens war das die übliche Methode der zuständigen Zensur auszuweichen, indem man über die Ereignisse auf dem benachbarten annektierten Gcbiet berichtete. Großpolen interessierte sich besonders für das kirchliche Leben auf dem russischen Annexionsgebiet. Die größten Verdienste für die Wiederbelebung des Kultus des $\mathrm{Hl}$. Kasimirs hat seine (im Polnisch geschribene) Lebensgeschichte (Das Leben, die Wunder und der Kultus des Hl. Kasimirs, des Prinzen von Litauen, Wilna 1858 und 1907) von A. Lipnicki, dem Professor des Priesterseminars, Prälat des Domkapitels von Wilna. Die dort geschilderte musterhafte Gestalt des H1. Kasimir, als des „Schutzheiligen der Nation” und „Patrons der Jugend (von den Jesuiten im 17. und 18. Jh. sehr propagiert). wurde gegen Ende des 19. Jhs zu einem wichtigen Bestandteil der Lehre über den Hl. Kasimir, sowie auch der an ihn gerichteten Gottesdienste. Beide Muster ergänzten einander vorzüglich. Man darf sich also nicht wundern, dą P. Alois Jougan seiner 1896 in Lemberg für die Gymnasialjugend abgehaltenen Predigt über den H1. Kasimir den Titel gab: Uber die Liebe zum Vaterland.

In der ersten Hälfte des 19. Jhs gibt es keine neuen Formen dieses Heiligenkultus. Es wirken nur die alten strukturalen Formen seiner Verehrung im Sanktuarium in Wilna und in den St. Kasimir-Kirchen anderer Städte fort (am häufigsten: Ablässe). Sie erfuhren aber alle eine Schwächung infolge der Napoleonischen Kriege und Einschränkungen, unter denen die Kirche seitens der Teilungsmächte, vor allem seitens der Russen, litt.

Das in der zweiten Hälfte des 19. Jhs auffallende größere Interesse für die Verehrung des Hl. Kasimirs hatte seine Quelle nicht nur in der Entwicklung des religiösen Lebens auf dem polnischen Boden, sondern auch in der patriotischen Tätigkeit der Polen, die sich für die Entwicklung des Kultus der Schutzheiligen Polens eingesetzt hatten. Das im Jahr 1884 veranstaltete Jubiläum des 400. Todestages von Hl. Kasimirs (Wilna, Krakau, Posen) hat der polnischen Nation die Gesialt dieses Heiligen näher gebracht. 